\title{
KUALITAS PELAYANAN KESEHATAN DI RUMAH SAKIT UMUM DAERAH M. YUNUS BENGKULU
}

\author{
OLEH : \\ YUSUARSONO \\ Dosen Prodi Administrasi Publik Fakultas Ilmu Sosial UNIVED Bengkulu
}

\begin{abstract}
Based on the preliminary survey I conducted at RSUD M. Yunus Bengkulu, there were a number of patients who complained to the services provided by the inner disease clinic. They were unsatisfied with the readiness of officials in giving services and the irregular schedule for medical check-up. They also complained with the time provided by the officials in giving services, which was too short, i.e. starling from 8.00 to 11.30 west Indonesia time. Indeed, the officials often give services star from 9.00 (one hour delay from the schedule), so that the patients felt that the officials carried out the services unprofessionally. This research aims to describe the quality of services provided by the nurses, doctors, and administrative staff in the clinic of inner disease at M. Yunus hospital, Bengkulu. Samples in this research were selected by using accidental sampling method. The data were collected using questionnaire. The collected data that were then analyzed using descriptive qualitative method. The finding shows that the services provided by both nurses and administrative staff were not satisfying. The medical services provided by the doctors in contras were in good quality.
\end{abstract}

Keywords : quality service of nurses, doctors, and administrators.

\section{PENDAHULUAN}

Pelayanan publik merupakan kegiatan atau rangkaian pelayanan yang sesuai dengan Undang-Undang No 25 tahun 2009 tentang pelayanan publik yang tidak dibarengi dengan keterbukaan informasi publik akan menjauhkan harapan masyarakat terhadap kualitas pelayanan itu sendiri dan akan dapat menimbulkan penyalahgunaan kewenangan dari pejabat negara yang seharusnya memberikan pelayanan kepada publik. Hak atas informasi menjadi sangat penting karena makin terbuka penyelenggaraan negara untuk diawasi publik, penyelenggaraan negara tersebut makin dapat dipertanggungjawabkan. Hak setiap orang untuk memperoleh informasi juga relevan untuk meningkatkan kualitas pelayanan dan juga melibatkan masyarakat dalam proses pengambilan keputusan publik. Pelayanan publik, partisipasi atau pelibatan masyarakat tidak banyak berarti tanpa jaminan keterbukaan informasi publik (Ibrahim 2008:48).

Azwar (1999) mengatakan bahwa untuk mengatasi perbedaan di atas seyogyanya yang dipakai 
pedoman adalah hakikat dasar dari penyelenggaraan pelayanan kesehatan, yaitu memenuhi kebutuhan dan tuntutan para pemakai jasa pelayanan kesehatan. Mutu pelayanan menunjukkan tingkat kesempurnaan pelayanan kesehatan dalam memenuhi kebutuhan dan tututan setiap pasien. Pemerintah melalui Keputusan Menteri Pendayagunaan Aparatur Negara (Menpan) Nomor 81 Tahun 1995 telah memberikan berbagai rambu-rambu pelayanan kepada birokrasi publik secara baik, yaitu dengan prinsip pelayanan seperti kesederhanaan, kejelasan, kepastian, keamanan, keterbukaan, efisiensi, ekonomis, dan keadilan yang merata. Pembangunan kesehatan meliputi berbagai bidang, baik fisik seperti gedung rumah sakit, puskesmas dan sebagainya, maupun non fisik seperti pembangunan manusianya baik mental maupun kemampuan intelektualnya dalam bidang kesehatan. Berry (1990:37) mengemukakan bahwa kinerja pelayanan publik yang baik dapat dilihat melalui berbagai indikator yang sifatnya fisik yang diberikan, seperti tersedianya gedung pelayanan yang resfresentatif, fasilitas pelayanan berupa televisi, ruang tunggu yang nyaman, peralatan pendukung yang memiliki teknologi yang canggih misalnya komputer, penampilan aparat pelayanan menarik dimata pengguna jasa, seperti seragam, dan aksesoris, serta berbagai fasilitas kantor pelayanan yang memudahkan akses pelayanan bagi masyarakat.

Pembangunan kesehatan juga akan tercapai apabila memiliki sumberdaya yang berkualitas.
Sumber daya manusia merupakan hal yang paling utama dalam pelayanan di bidang kesehatan yang berkualitas. Sumber daya manusia dalam bidang kesehatan adalah tenaga kesehatan. Tenaga kesehatan adalah setiap orang yang mengabdikan diri dalam bidang kesehatan serta memiliki pengetahuan dan atau keterampilan melalui pendidikan di bidang kesehatan, yang untuk jenis tertentu memerlukan kewenangan untuk melakukan upaya kesehatan (Undang-Undang Republik Indonesia Nomor 23 Tahun 1992).

Dalam penyelenggaraan pelayanan publik di rumah sakit, tenaga kesehatan yang ada di rumah sakit mempunyai peranan yang sangat penting karena dari tenaga kesehatan rumah sakitlah pelayanan publik dapat berkualitas dan berjalan sesuai dengan harapan masyarakat. Untuk mengetahui kualitas pelayanan publik di rumah sakit pada masa lampau dan pada saat ini, dapat diperoleh dengan mengadakan analisis historis terhadap data pelayanan dari tahun ke tahun. Hasil analisis historis tersebut dapat digunakan sebagai bahan pertimbangan dalam menyusun rencana serta kebijaksanaan yang akan dilaksanakan pada waktu mendatang. Pada dasarnya pelayanan publik di rumah sakit bertujuan untuk memenuhi kebutuhan dan tuntutan masyarakat terhadap pelayanan kesehatan, sehingga kesehatan masyarakat dapat terpelihara dan mutu pelayanan yang dikaitkan dengan kehendak untuk memenuhi kebutuhan serta tuntutan pemakai jasa pelayanan menuju pada tingkat kesempurnaan pelayanan 
kesehatan dalam memenuhi kebutuhan dan tuntutan tiap pasien.

Keluhan yang diterima oleh pasien (masyarakat) yang merasa tidak puas atas pelayanan kesehatan yang mereka terima, baik dari dokter, perawat, bidan ataupun tenagatenaga kesehatan lainnya. Beragam ada yang karena petugas kesehatan sering lamban memberikan pelayanan, administrasi yang berbelit-belit, ada yang karena dokter sering terlambat menangani pasien, kurangnya sarana dan prasarana pendukung lainnya. Lebih tragis lagi ada petugas kesehatan yang cenderung pilih kasih dalam menangani pasien, serta membebankan biaya tertentu kepada pasien walaupun hal tersebut sebenarnya gratis ( Mahmudi 2003). Atas berbagai persoalan tersebut, baik dokter, bidan, perawat maupun tenaga kesehatan lainya yang ada di rumah sakit selalu memberikan alasan pada persoalan mis komunikasi saja.

Penelitian ini memfokuskan pada kualitas pelayanan kesehatan di rumah sakit, di poli klinik penyakit dalam, pelayanan dokter dan perawat di ruang penyakit dalam, dan bagian administrasi poli klinik penyakit dalam dengan lokus penelitian yaitu Rumah Sakit Umum Daerah M. Yunus Bengkulu.

Masalah pokok dalam penelitian ini adalah bagaimanakah kualitas pelayanandi ruang poli klinik penyakit dalam Rumah Sakit Umum M. Yunus Bengkulu? Pertanyaan penelitian dirincikan dalam rumusan masalah sebagai berikut:

1. Bagaimanakah kualitas pelayanan perawat di ruang poli penyakit dalam RSUD M. Yunus Bengkulu dilihat dari demensi buktifisik, keandalan, dayatanggap, jaminan,danempati?

2. Bagaimanakah kualitas pelayanan dokter di ruang poli penyakit dalam RSUD M. Yunus Bengkulu ditinjau dari demensi buktifisik, keandalan, dayatanggap,jaminandanempati?

3. Bagaimanakah kualitas pelayanan administrasi di ruang poli penyakit dalam RUSD M. Yunus Bengkulu dipandang dari demensi buktifisik, keandalan, dayatanggap, jaminandanempati?

\section{METODE PENELITIAN}

Penelitian ini adalah penelitian dengan menggunakan pendekatan deskriptif, yaitu suatu penelitian yang mendapatkan data akurat dan faktual dari suatu daerah/objek penelitian tertentu, dimana data tersebut dibahas dan diuraikan secara sistematis, kemudian disimpulkan sebagai hasil pemecahan masalah yang diteliti (Sugiono,2008).

Penelitian deskriptif bertujuan untuk memperoleh informasiinformasi keadaan saat ini dan kaitanya dengan indikator yang ada pada penelitian ini. Penelitian ini tidak menguji hipotesis, melaikan hanya mendeskripsikan informasi yang apa adanya sesuai dengan yang diteliti (Hastono, 2001). Dengan pendekatan deskriptif hasil yang diteliti difokuskan pada kualitas pelayanan perawat, kualitas pelayanan dokter, dan kualitas pelayanan administrasi di RUSD M. Yunus Bengkulu. 
Penelitian ini menggunakan teknik analisis data kuantitatif. Analisis data kuantitatif dilakukan untuk mencari nilai rata-rata dari persepsi kualitas pelayanan perawat, dokter, administrasi jumlah seluruh nilai data dibagi banyaknya kejadian atau frekuensi.

\section{HASIL PENELITIAN DAN PEMBAHASAN}

Uraian berikut menyajikan semua hasil penelitian tentang kualitas pelayanaan ruang penyakit dalam RSUD M.Yunus Bengkulu, di antaranya pelayanan keperawatan, pelayanan dokter, dan pelayanan petugas administrasi yang tersedia dengan bantuan SPPSForWindows untuk mencari frekuensi dan rata-rata total jawaban responden

\section{Tanggapan Responden Terhadap Pelayanan Perawat.}

Berdasarkan hasil kuesioner dan seluruh responden yang diwawancarai dalam aspek reliability (keandalan), semuanya mengatakan pelayanan perawat yang diterima oleh pasien atau keluarganya kurang berkualitas karena perawat kurang ramah, pelayanannya tidak sesuai dengan yang dijanjikanya, dan kinerja perawat kurang memuaskan dalam hal pengobatan dan pemeriksaan penyakit pasien.

Aspek responsiveness (ketanggapan), seluruh responden yang diwawancarai semuanya mengatakan perawat dalam melayani pasien kurang berkualitas karena perawat tidak mampu menyelesaikan keluhan penyakit pasien, perawat dalam melayani pasien kurang bersikap ramah, dan perawat kurang respon atas penyakit pasien dalam pengobatan dan pemeriksaan.

Aspek

anssurance (jaminan),seluruh responden yang diwawancarai semuanya mengatakan perawat dalam memberikan pelayanan kurang ramah dan perhatian pada pasien dalam memberikan pelayanan, kurang memberikan informasi tentang penyakit pasien dan kurang memberikan jaminan keamanan pelayanan pengobatan dan pemeriksaan penyakit pasien.

Aspek empathy (empati),seluruh responden yang diwawancarai semua mengatakan perawat sulit untuk dihubungi ketika dimintak pertolongan pengobatan, tidak pernah menjaga hubungan baik dengan pasien atau keluarga pasien saat pengobatan, dan jarang sekali perawat memahami keinginan pengobatan pasien yang berobat atas kesebuhan penyakitnya.

Aspek tangibles (bukti langsung), seluruh responden yang diwawancarai mengatakan penampilan perawat dalam memberikan pelayanan cukup baik, perawat menjaga kelengkapan peralatan medis yang digunakan untuk pengobatan dan pemeriksaan penyakit pasien, perawat menjaga kebersihan,kerapian dan kenyamanan disaat pasien sedang berobat, dan kondisi tempat berobat krang baik untuk melayani pasien.

Hasil dari beberapa aspek diatas yang perlu dilakukan untuk memperbaiki kualitas pelayanan perawat pada aspek responsiveness (ketanggapan), karena pada tahap inilah perlu diperhatikan untuk meningkatkan kualitas pelayanan 
perawat diberikan pengarahan dan pejelasan tentang fungsi perawat dalam melayani pasien, respon perawat dalam memberikan pelayana, dan penanganan penyakit pasien yang sesuai dengan penyakitnya.

Berdasarkan tanggapan responden terhadap pelayanan perawat dapat diketahui bahwa pelayanan keperawatan di rung poli klinik penyakit dalam dengan skor nilai rata-rata jawaban responden adalah sebesar 2.60 dengan katagori kurang berkualitas, karena skor yang diperoleh pada rentang 1,81-2,60 artinya hasil penelitian tersebut dapat disimpulkan bahwa pelayanan keperawatan di ruang Poli Penyakit Dalam RSUD M. Yunus kurang berkualitas.

Persepsi responden terhadap pelayanan perawat dengan skor nilai tertinggi jawaban responden adalah sebesar 2.98 cukup berkualitas karena perawat menjaga kelengkapan, kesiapan dan peralatan medis untuk memberikan pelayanan pengobatan penyakit pasien atau keluarganya.

Demikian pula persepsi responden terhadap pelayanan keperawatan dengan skor terendah jawaban responden adalah sebesar 2.50 artinya kurang berkualitas karena ruangan pengobatan dan pemeriksaan di poli klinik penyakit dalam tidak layak untuk ditempati sehingga kondisi ruangan yang sempit, pasien terlalu lama menunggu pangilan untuk pengobatan dan pemeriksaan.

\section{Tanggapan Responden Terhadap Pelayanan Medis/Dokter}

Berdasarkan hasil kuesioner dan seluruh responden yang diwawancarai dalam aspek reliability (keandalan), seluruh responden yang diwawancarai semuanya mengatakan pelayanan pemeriksaan yang dilakukan dokter cukup baik, dokter dalam memberikan pemeriksaan dan pengobatan santai, bersahabat dan penuh perhatian pada semua pasien, dokter dalam melakukan pengobatan penyakit pasien sesuai dengan yang dijanjikan atas kesembuhannya, dan kinerja dokter dengan hasil yang memuaskan ketika memberikan pelayanan pengobatan dan pemeriksaan.

Aspek responsvenees (ketanggapan), seluruh responden yang diwawancarai semuanya responden yang diwawancarai mengatakan pemeriksaan yang dilakukan dokter baik, karena dokter cepat melayani pasien untuk pengobatan, cepat mengambil penanganan pasien yang sedang sakit, dan dokter cepat membantu penangganan keluhan penyakit pasien yang sedang sakit untuk mendapatkan pengobatan dan pemeriksaan penyakit pasien.

Aspek anssurance (jaminan), seleruh responden yang diwawancarai semuanya mengatakan pelayanan pemeriksaan dan pengobatan dokter baik, karena dokter dalam bekerja ramah, sopan, perhatian dan memberikan pelayanan pengobatan penyakit pasien, dokter memberikan informasi atas tindakan yang diambil untuk menolong pasien dalam pengobatannya, dokter memberikan penjelasan aturan makan obat, dokter dalam memberikan penjelasan hasil diagnosis pada pasien atau keluarganya, dokter memberikan 
penjelasan larangan makanan yang harus dihindari ketika sedang berobat dan dokter memberikan waktu untuk konsultasi pada pasien atau keluarganya walaupun waktunya terbatas. $\begin{array}{crr}\text { Aspek } & \begin{array}{r}\text { empathy } \\ \text { responden }\end{array} & \text { (empati), } \\ \text { seluruh } & \text { yang }\end{array}$ diwawancarai semuanya mengatakan pelayanan dan pemeriksaan dokter baik karena, dokter memberikan jaminan keaman pelayanan yang diberikan atas kesebuhan penyakit pasien, cepat tanggap ketika dihubungi oleh keluarga pasien untuk dimintak pertolongannya, dokter selalu menjaga hubungnan baik dengan pasien ketika mengobati dan pemeriksaan penyakit pasien, dan dokter berusaha dengan maksimal untuk menyembuhkan penyakit pasien.

Aspek tangibles (bukti langsung), seluruh responden yang diwawancarai semuanya mengatakan pelayanan dokter dalam penampilanya cukup baik ketika memeriksa penyakit pasien, dokter selalu mengecek kelengkapan peralatan medis yang akan digunakan untuk pemeriksaan dan pengobatan pasien dan dokter menjaga kebersian tempat untuk pengobatan dan pemeriksaan penyakit pasien.

Hasil penelitan dari beberapa aspek diatas, aspek anssuransi (jaminan), yang perlu diperhatikan diantaranya pelayanan pengobatan dan pemeriksaan penyakit pasien perlu ditingkatkan dokter tetap bersipat sopan, perhatian, ramah dalam memberikan pelayanan, dokter cepat bertindak ketika pasien membutuhkan pengobatan, dokter lebih sering mengiatkan pasien tentang aturan makan obat, dokter lebih cermat lagi menentukan hasil diagnosis penyakit pasien, dokter sering mengiatkan pasien tentang makanan yang tidak boleh dimakan saat masih sakit, dan dokter memberikan banyak waktu untuk konsultasi masalah penyakit pasien.

Berdasarkan

tanggapan responden terhadap pelayanan dokter di ruang polikelinik penyakit dalam dapat diketahui bahwa dengan skor nilai rata-rata jawaban responden adalah 3.79 dengan kata gori berkualitas, karena skor yang diperoleh pada rentang 3,41-4,24 artinya hasil penelitian tersebut menunjukkan bahwa pelayanan dokter di ruang Poli Penyakit Dalam RSUD M. Yunus Bengkulu berkualitas.

Persepsi responden terhadap pelayanan dokter dengan skor nilai tertinggi jawaban responden adalah sebesar 4.23 artinya berkualitas karena di ruang poli penyakit dalam dokter menjaga kelengkapan, kesiapan dan peralatan medis yang digunakan untuk pemeriksaan dan pengobatan penyakit pasien.

Demikian pula persepsi responden terhadap pelayanan dokter dengan skor nilai terendah jawaban responden adalah sebesar 3.22 artinya cukup berkualitas karena dokter dalam bekerja selalu bersikap ramah, perhatian, sopan dan memberikan pelayanan pengobatan dan pemeriksaan penyakit pasien.

\section{Tanggapan Responden Terhadap Pelayanan Administrasi}

Berdasarkan hasil kuesioner dan seluruh responden yang diwawancarai dalam aspek reliability (keandalan), semuanya mengatakan pelayanan administrasi kurang cepat 
dan baik, apalagi ketika memberikan pelayanan pada keluarga pasien, dan dalam bekerja petugas administrasi memberikan penjelasan kepada keluarga pasien saat pengurusan administrasi maupun kira-kira biaya yang digunakan sehiga kita sebagai keluarga pasien tidak puas atas jawabannya.

Aspek

responsivenees

(ketanggapan), seluruh responden yang diwawancarai semuanya mengatakan pelayanannya kurang cepat, dan petugas administrasi dalam memberikan pelayanan kepada keluarga pasien sesuai dengan prosedur pelayanan belum cukup baik buktinya dalam pengurusannya prosesnya yang sangat panjang harus dilalui.

Aspek anssurance (jaminan), responden yang diwawancarai keduanya mengatakan pelayanannya kurang baik karena petugas administrasi kurang ramah dan perhatian memberikan pelayanan pada keluarga pasien, kurang memberikan penjelasan biaya yang harus dikeluarkan ketika berobat, cukup memberikan jaminan keamanan dengan memberikan bukti pembayaran pengobatan pasien. Aspek empathy (empati),responden yang diwawancarai keduanya mengatakan cukup baik karena petugas administrasi memberikan pelayanan cukup perhatian, adanya hubungan timbal balik dengan pasien dengan mencatat alamat pasien untuk mudah dihubungi, petugas administrasi sulit untuk dihubungi untuk dimintak pertolongan pelayanan ketika dibutuhkan.
Aspek tangibles (bukti langsung), seluruh responden yang diwawancarai semunya menyatakan kebersihan dan kerapian pelayanan administrasi baik menjaga kerapian dan kebersihan loket, petugas administrasi menjaga kelengkapan dan kesiapan peralatan untuk memberikan pelayanan pada keluarga pasien, dan ruangan pelayanan sempit tidak layak untuk memberikan pelayanan.

Hasil penelitian administrasi dari beberapa aspek diatas, aspek responsiveness (ketanggapan), yang perlu diperhatikan karena dalam pelayanan petugas administrasi terlalu banyak prodedur yang dilalui hendaknya memberikan proses satu atap, memberikan penjelasan yang tuntas pada keluarga pasien ketika melayani keluarganya.

Berdasarkan tanggapan responden terhadap pelayanan administrasi di ruang poli klinik penyakit dalam dapat diketahui bahwa skor nilai rata-rata jawaban responden adalah sebesar 2.59 dengan katagori kurang berkualitas, karena skor yang diperoleh pada rentang 1,81-2,60 artinya hasil penelitian tersebut dapat disimpulkan bahwa pelayanan administrasi di ruang Poli Penyakit Dalam RSUD M. Yunus Bengkulu kurang berkualitas.

Persepsi responden terhadap pelayanan administrasi dengan skor nilai tertinggi jawaban responden adalah sebesar 2.65 artinya petugas administrasi di ruang poli penyakit dalam selalu menjaga kelengkapan dan kesiapan untuk memberikan pelayanan kepada keluarga pasien.

Demikian pula persepsi responden terhadap pelayanan administrasi 
dengan skor terendah jawaban responden adalah sebesar 2.34 artinya kurang berkualitas karena ruangan administrasi di poli klinik penyakit dalam kondisi ruangannya terlalu sempit dan kurang layak untuk ditempati ketika petugas memberikan pelayanan kepada keluarga pasien.

Hasil pengamatan dilapangan menunjukkan bahwa kualitas pelayanan administrasi masih kurang. Buktinya petugas tidak memberikan penjelasan kepada pasien(keluarga pasien) tentang informasi yang diperlukan, petugas administrasi tidak bersikap ramah dalam melayani keluarga pasien pada saat pengurusan administrasi.

Sementara itu, hasil penelitian yang lakukan di lapangan saat pengurusan izin sangatlah sulit. Mereka cenderung mempersulit dan berbelit-belit yang beberapa tahapan harus dilalui, akan tetapi mereka nampaknya terlalu kaku untuk memperoleh data. Apalagi harus memasukan surat penelitian dari bagian pendidikan dan pelatihan diwajibkan menunjukkan surat pengantar baru bisa mendapatkan data yang dibutuhkan.

\section{PEMBAHASAN}

Hasil penelitian menunjukkan bahwa pelayanan perawatan secara umum dengan skor nilai rata-rata jawaban responden adalah sebesar 2.60 artinya hasil penelitian tersebut dapat disimpulkan bahwa pelayanan perawat di ruang Poli Penyakit Dalam RSUD M.Yunus Bengkulu kurang berkualitas. Hal ini terlihat dari kenyataannya bahwa perawat kurang menjaga kerapian, kebersihan penampilan dalam memberikan pelayanan keperawatan kepada pasien, kurang membantu pasien mau berobat, sulit untuk dihububungi, sehingga pasien yang menerima pelayanan keperawatan kurang berkualitas.

Perawat di ruang poli penyakit dalam belum ramah dalam melayani pasien walaupun masih kurang cekatan, dan kurangnya inisiatif sehingga banyak yang hanya menunggu perintah dokter atau perawat senior, dalam ruangan ini juga perawat masih kurang berperan sesuai dengan fungsinya. Fungsi perawat sebagai pemberi asuhan keperawatan, pelindungan advokasi pasien, sebagai pendidik, kolborasi dengan ahli gizi, dan peran lainnya.

Perawat yang menjadi tugas pokok kebanyakan temuan lain perawat yang melayani pasien adalah perawat yang praktik, sehingga belum berpengalaman dalam melayani, ditambah dengan jumlah pasien yang banyak membutuhkan pelayanan yang maksimal.

\section{Pelayanan Medis / Dokter}

Hasil penelitian menunjukkan bahwa pelayanan dokter secara umum dengan skor nilai rata-rata jawaban responden adalah sebesar 3.79 artinya hasil penelitian tersebut dapat disimpulkan bahwa pelayanan dokter di ruang Poli Penyakit Dalam RSUD M. Yunus Bengkulu berkualitas. Hal ini disebabkan dokter bertindak cepat mengambil tindakan perawatan, mampu menyelesaikan keluhan penyakit pasien, adanya jaminan keamanan, pemeriksaan dan pengobatan, dalam bekerja dokter bersikap ramah, sopan dan perhatian pada setiap pasien yang berobat, dokter dapat 
menentukan ketepatan hasil diagnosa penyakit pasien dan dokter memberikan informasi yang jelas tentang penyakit yang dideritanya.

Menurut Rachel Massie (dalam Tjandra, 2003) pelayanan rumah sakit amat dipengaruhi oleh para profesional biasanya cenderung sangat otonom, tetapi dengan adanya perubahan paradigma pelayanan rumah sakit, maka para dokter mempunyai tanggungjawab memberikan pelayanan kepada pasien sesuai dengan kode etik dan berorientasi pada kepuasan pasien.

\section{Pelayanan Administrasi}

Hasil penelitian menunjukkan bahwa pelayanan administrasi secara umum dengan skor nilai rata-rata jawaban responden adalah sebesar 2.59 artinya hasil penelitian tersebut dapat disimpulkan bahwa pelayanan administrasi di ruang Poli Penyakit Dalam RSUD M.Yunus Bengkulu kurang berkualitas. Hal ini terjadinya pelayanan administrasi masih kurang cepat tanggap memberikan pelayanan, masih kurang sesuai dengan pelayanan yang telah dijanjikan, masih kurangnya jaminan keamanan, masih kurang ramah, dan prosedur pedaftaran berbelit-belit, masih kurang siapnya peralatan pelayanan. Berdasarkan penelitian yang saya lakukan kebanyakan pasien banyak yang mengeluhkan sistem pendaftaran yang begitu banyak persyaratan yang harus dipenuhi oleh pasien dan lamanya menunggu pangilan.

Selain itu waktu yang sangat terbatas seperti jadwal rawat jalan di poli penyakit dalam pada Senin sampai Jumat dibuka pukul 08.00
WIB sampai pukul 11.00 WIB, dan Jum'at dari pukul 08.00 WIB sampai pukul 10.00 WIB. Pasien yang berobat perhari rata-rata 100 orang dapat dibayangkan singkatnya waktu pengobatan, sedangkan sesuai dengan sistem pelayanan minimal rumah sakit jadwal pelayanan kepada pasien dari jam 08.00 WIB sampai 13.00 WIB, jadi pelayanan yang dilakukan administrasi tidak sesuai dengan sistem pelayanan rumah sakit. Tenagga administrasi yang kebanyakan sudah berumur juga mempengaruhi kecepatan, ketepatan, dan kelincahan dalam melayani pasien.

Hasil penelitian ini sejalan dengan pendapat Moenir (2002:91) bahwa di kantor yang bagimana kecilnya terdapat dua macam pelayanan, pertama pelayanan kedalam yaitu pelayanan kepada manajemen, yang kedua pelayanan keluar yaitu pelayanan yang sifatnya pelaksanaan kebutuhan organisasi di bidang produksi, pengadaan, penyimpanan, data informasi, komunikasi, pembinaan sistem, prosedur dan metode dan ketatausahaan pada umumya. Berbagai kegiatan tersebut berdampak pada pelayanan keluar bahkan dikatakan bahwa pelayanan kedalam menjadi ukuran terhadap pelayanan keluar. Jika pelayanan kedalam cukup baik, lancar dan tertib maka dapat diharapkan bahwa pelayanan keluar akan tertib dan lancar pula.

\section{PENUTUP}

\section{Kesimpulan}

Hasil penelitian menunjukkan bahwa pelayanan perawat di poli 
penyakit dalam kurang berkualitas (2.60), dikarenakan kualitas pelayanan di ruang poli klinik penyakit dalam perawat kurang membantu pasien dalam berobat, masih sulit dihubungi, kurang ramah pada pasien atau keluarganya, kurang cekatan dalam bekerja, kurang inisiatif dan masih menunggu perintah perawat senior. Yang dilakukan oleh perawat kurang memberikan pelayanan dan kenyamanan pasien yang berobat di poli klinik penyakit dalam.

Hasil penelitian ini sejalan dengan pendapat Griffith (dalam Tjandra 2003:72) bahwa kegiatan keperawatan di rumah sakit dapat dibagi ke dalam keperawatan klinik. Kegiatan keperawatan klinik terdiri dari atas : 1). Pelayanan keperawatan personal yang berupa pelayanan keperawatan umum atau spesifik untuk sistem tubuh tertentu, pemberian motivasi, dan dukungan emosi pada pasien pemberian obat. 2). Berkomunikasi dengan dokter dan petugas penujang medik, mengingat perawat selalu berkomunikasi dengan pasien setiap waktu. 3). Menjalin hubungan dengan keluarga pasien, komunikasi dengan baik dengan keluarga/kerabat pasien untuk membantu penyembuhan pasien. 4). Menjaga lingkungan bangsal tempat perawatan, waktu zaman telah berubah perawat tidak lagi mengepel lantai tetapi perawat tetap bertanggungjawab lingkungan bangsal perawat pasien, baik lingkungan pisik, mikrobiologik, maupun keamanan. 5). Melakukan penyuluhan kesehatan dan upaya pencegahan penyakit.
Hasil penelitian menunjukkan bahwa pelayanan medis/dokter di poli penyakit dalamberkualitas (3.79), hal ini disebabkan dokter di ruang penyakit dalam dokter bertindak cepat dalam mengambil tindakan keperawatan, mampu menyelesaikan keluhan penyakit pasien, adanya jaminan keamanan, pemeriksaan dan pengobatan, dalam bekerja dokter selalu bersikap ramah, sopan dan perhatian pada setiap pasien yang berobat, dokter dapat menentukan hasil diagnosis penyakit pasien dan dokter memberikan informasi yang jelas tentang penyakit yang diderita pasien.

Hasil penelitian ini sejalan
dengan
(2005:68) bahwa mutuh pelayanan kesehata. 1). Terbinanya dokter dengan pasien yang baik adalah salah satu dari kewajiban etik, dokter dapat bersedia memberikan perhatian yang cukup kepada pasiennya secara pribadi, menampung dan mendengarkan semua keluhan. Menjawab dan memberikan keterangan yang sejelas-jelasnya tentang segalah hal yang ingin diketahui oleh pasien. 2). Kenyamanan tidak hanya menyangkut fasilitas yang disediakan, tetapi yang terpenting adalah sikap serta tindakan para pelaksana ketika menyelenggarakan pelayanan kesehatan. 3). Suatu pelayanan dikatakan bermutu apabilah kebebasan memilih dapat memberikan kepuasan pasien, karena itu harus dapat dilaksanakan oleh setiap penyelenggara pelayanan kesehatan.

Hasil penelitian menunjukkan bahwa pelayanan administrasi secara umum kurang berkualitas (2.59), karena 
sikap petugas administrasi tidak dapat memberikan pelayanan yang maksimal, kurang cepat dan tanggap memberikan pelayanan, masih kurang sesuai dengan pelayanan yang dijanjikan, masih kurangnya jaminan keamanan, kurang ramah, dan masih kurangnya peralatan pelayanan. Dengan demikian pelayanan administrasi masih belum berkualitas.

Hasil penelitian ini sejalan dengan pendapat The Liang Gei (2002:81) administrasi secara sempit atau ketata usahaan adalah kegiatan yang meliputi pekerjaan menghimpun, mencatat, mengelola, mengirim dan menyimpan keterangan-keterangan yang diperlukan dalam setiap usaha kerjasama, kelancaran pekerjaan tata usaha dalam organisasi merupakan modal yang berharga dalam rangka mencapai tujuan ahir organisasi.

\section{Saran}

Kepada perawat rumah sakit umum hendaknya dapat memperbaiki kualitas pelayanan seperti bersikap ramah kepada pasien, memberikan pelayanan yang cepat dan tanggap. Selain itu perawat juga memberikan kenyamanan kepada pasien yang berobat di poli penyakit dalam sehingga terciptanya rasa aman, dan nyaman bagi pasien.

Kepada dokter rumah sakit hendaknya tetap komitmen dan dapat mempertahankan, meningkatkan pelayanan yang berkualitas dengan melaksanakan jadwal tepat waktu yang sudah menjadi aturan rumah sakit. Pasien tidak menunggu dokter lama datang, kemudian dokter memberikan informasi yang jelas jangan sampai terjadinya salah diagnosis.

Kepada petugas administrasi dapat memperbaiki pelayanan, memberikan informasi yang jelas, masalah prosedur administrasi yang diperlukan oleh pasien dan keluarga pasien. Dalam hal pelayanan yang meliputi prosedur pendaftaran, kelengkapan sarana dan prasarana, kejelasan informasi pelayanan. Oleh karena itu komponen-komponen sistem pelayanan tersebut perlu ditingkatkan melalui pelaksanaan prosedur pendaftaran yang cepat dan efisien, melengkapi sarana dan prasarana yang menunjang pelayanan, memberikan informasi secara tepat dan akurat kepada pasien, pemeriksaan yang berkesinambungan oleh petugas yang sama sesuai dengan bidangnya, hal ini perlu dilakukan untuk meningkatkan kualitas pelayanan dalam upaya mewujudkan kepuasan pasien.

\section{DAFTAR PUSTAKA}

Adya. 2003. Dasar-Dasar Pelayanan Prima. Jakarta, PT. Elex Media Kompotindo

Atmosudirjo. 2003. Tiory Administrasi. Jakarta, Stialan

Azwar.1994. Program Menjaga Mutu Pelayanan Kesehatan. Jakarta, Yayasan IDI

Depkes RI. 2002. Pedoman
Pemantauan Berkala
Kepusan Penggunaan Jasa
Puskesmas, Jakarta


Faridah. 2004. Kualitas Pelayanan dan Kepuasan Pelanggan Studi di Ruang Rawat Inap di Rumah Sakit Umum Sleman Bandung,. Universitas Padjadjaran

Hidayat. 2006. Pengantar Konsep DasarKeperawatan. Jakarta, Salimba Medeka

$\begin{array}{cr}\text { Huberman. 2005. Memahami } \\ \text { Penelitian } & \text { Kualitatif } \\ \text { Jakarta, Renika Cipta }\end{array}$

Ibrahim. 2008. Teori dan Konsep Pelayanan Publik Serata Implementasi. Jakarta, Penerbit CV. Mandar Maju..

Irfan. 1998. Agen Kebijaksanaan Reformasi Administrasi Negara. Malang

Kirom. 2010. Mengukur Kinerja Pelayanan dan Kepuasan Konsumen, Penerbit Pustaka Reca Cipta

Menkes. 2006. Keputusan Mentri Kesehatan RI Tentang Status RSUD Tipe B. Pendidikan no 1413 Menkes / SK / XI / 2006.

Menpan.1993. Keputusan Mentri Pendayagunaan Aparatur Negara (MENPAN) No 81tahun 1993 Tentang Pedoman Tata Laksana Pelayanan Umum. Jakarta

$\begin{array}{cc}\text { Menpan. 2005. } & \text { Peraturan } \\ \text { Pemerintah (PP) } & \text { No } 23 \\ \text { tahun 2005 } & \text { Tentang } \\ \text { Pengelolaan } & \text { Keuangan } \\ \text { Badan Layanan } & \text { Umum, } \\ \text { Jakarta } & \end{array}$

Moenir.2002. Manajemen Pelayanan Umum diIndonesia. Jakarta, Bumi Aksara

Moelljono. 2004. Budaya Koprat dan Keunggulan Koprasi. Jakarta, PT. Elex Media Kompolindo

Parasuraman. 1998. Multiple Item Scale For Mersuring Costomer Persepsion Of Servince Quality, Journal Of Retailing.

Prajueli. 2003. Teory Administrasi. Jakarta, STIALAN

Rachmrawati, D. 2005. Pelayanana Rumah Sakit Yang Berkarakter. http : / puslit. Petra.ac id/Juornal / managemen.

Rasyid. 2000. Reformasi Politik dan Ekonomi. Jakarta, Wedyapraya

Sinambela. 2010. Reformasi Pelayanan Publik. Jakarta Penerbit Bumi Aksara.

Surjadi. 2009. Pengembangan Kinerja Pelayanan Publik., Penerbit Refika Aditama

Soroso. 2003. Manajemen Sumber Daya Manusia Di Rumah Sakit Suatu Pendekatan Sistem. EGC. Jakarta

Tjandra. 2003. Jaminan Mutu Pelayanan Kesehatan. Bekasi Indonesia

Tjipto. 1997. Tolal Quality Managemen. Jakarta Penerbit Andi 